\title{
Determinan yang Mempengaruhi Financial Performance pada Perusahaan Asuransi Umum Syariah di Indonesia
}

\author{
Sofiyatul Munawaroh \\ Prodi Akuntansi Universitas Negeri Semarang \\ Email: sofiyatul.munawaroh97@gmail.com \\ Hasan Mukhibad \\ Prodi Akuntansi Universitas Negeri Semarang \\ Email: hasanmukhibad@mail.unnes.ac.id
}

\begin{abstract}
Abstrak:
The aims of this research are to identify the impact of size, leverage, age, volume of capital growth, tabarru' funds, independent commissioner ratio, and investment growth on the financial performance in Sharia Non-Life Insurance Company in Indonesia during 2015-2017. The samples obtain 63 units of analysis are selected using purposive sampling method. The data is analysed using descriptive statistical analysis and panel data regressing in E Views 9. Result of this study indicate that size, age, and volume of capital growth have a positively and significantly effect. Investment growth have a negatively and significantly effect. Meanwhile, leverage, tabarru' fuds and independent commissioner ratio do not have significant effect on the financial performance. Suggestion in this research is the following researchers are expected to extend the duration of the study, so the results of the study become more accurate.

[Penelitian ini mempunyai tujuan untuk mengidentifikasi adanya pengaruh size (ukuran perusahaan), leverage (rasio hutang), age (umur perusahaan), pertumbuhan volume of capital, dana tabarru', rasio komisaris indepeden, dan pertumbuhan investasi pada financial performance perusahaan asuransi umum syariah di Indonesia periode tahun 2015-2017. Metode penentuan sampel dalam penelitian ini yaitu metode purposive sampling dan didapatlan hasil sebanyak 63 unit analisis. Analisis data dalam studi ini yaitu analisis deskriptif dan analisis regresi data panel dengan menggunakan tool E Views 9. Penelitian ini menghasilkan bahwa size (ukuran perusahaan), age (umur perusahaan), dan pertumbuhan volume of capital mempunyai pengaruh positif dan signifikan terhadap financial performance. Sementara itu, pertumbuhan investasi mempunyai pengaruh dengan arah negatif dan signifikan pada financial performance, sedangkan leverage (rasio hutang), dana tabarru', dan rasio komisaris independen tidak mempengaruhi financial performance. Saran dalam penelitian ini untuk menghasilkan penelitian lebih akurat maka sebaiknya penelitian selanjutnya dilakukan dalam jangka waktu yang lebih panjang.]
\end{abstract}

Kata Kunci: Determinan; Financial Performance; Asuransi; Pertumbuhan Investasi. 


\section{PENDAHULUAN}

Perkembangan asuransi syariah dalam jangka waktu beberapa tahun terakhir cukup baik di Indonesia. Persaingan yang ketat antar perusahaan tercipta karena pesatnya perkembangan industri perasuransian baik pada konvensional maupun unit syariah. Hingga akhir tahun 2017, penetrasi asuransi syariah masih sangat rendah yakni sebesar $0,104 \%$ padahal peluang asuransi syariah di Indonesia masih sangat luas karena mayoritas penduduk beragama Islam. Perusahaan asuransi syariah harus memanage dan mengelola aset dan pendapatan preminya secara optimal sehingga dapat memenuhi kriteria sebagai perusahaan asuransi yang sehat karena mempunyai kinerja keuangan yang baik. Apabila kinerja keuangan asuransi syariah baik, maka para investor tidak akan ragu dan lebih percaya untuk menginvestasikan dananya terhadap perusahaan asuransi syariah. Oleh sebab itu, determinan yang mempengaruhi financial performance perusahaan asuransi syariah di Indonesia dijadikan tema dalam penelitian ini.

Para peneliti terdahulu seperti Nurlatifah dan Mardian, ${ }^{1}$ meneliti sebanyak 30 asuransi unit syariah yang tercatat dan diawasi oleh Otoritas Jasa Keuangan dan menghasilkan bahwa firm size (ukuran perusahaan) mempunyai pengaruh secara positif pada financial performance. Leverage dan volume of capital mempunyai pengaruh dengan arah negatif pada financial performance. Liquidity, tanginility, dan loss ratio tidak mempengaruhi financial performance. Sementara itu Mehari dan Aemiro, ${ }^{2}$ meneliti determinan yang mempengaruhi kinerja keuangan pada industri asuransi syariah di Ethiopia. Hasil penelitian menunjukan bahwa ukuran perusahaan, tangibilitas, dan leverage mempunyai pengaruh dengan arah positif dan signifikan terhadap kinerja keuangan. Rasio kerugian mempunyai pengaruh dengan arah negatif dan signifikan terhadap kinerja keuangan. Umur perusahaan, likuiditas dan pertumbuhan premi tidak mempengaruhi kinerja keuangan. Penelitian Berhe dan Kaur, ${ }^{3}$ juga meneliti faktor-faktor yang mempengaruhi profitabilitas pada asuransi syariah di Ethiopia. Penelitian tersebut menghasilkan bahwa kecukupan modal, rasio likuiditas dan tingkat pertumbuhan PDB adalah faktor utama yang secara signifikan mempengaruhi profitabilitas perusahaan asuransi. Rasio leverage, rasio kerugian, pangsa pasar dan tingkat tidak mempengaruhi secara signifikan terhadap profitabilitas asuransi syariah.

Beberapa peneliti terdahulu telah meneliti faktor-faktor yang mempengaruhi kinerja keuangan asuransi syariah. Dalam penelitian ini digunakan tujuh variabel yaitu size (ukuran perusahaan), leverage (rasio hutang), age (umur perusahaan), pertumbuhan volume of capital, dana tabarru', rasio komisaris independen, dan pertumbuhan investasi.

Teori yang digunakan dalam penelitian adalah teori stakeholder, resource-based theory dan pecking order theory. Teori stakeholder menjelaskan bahwa suatu operasi dalam perusahaan tidak hanya untuk kepentingan pemilik perusahaan, akan tetapi juga harus bermanfaat bagi stakeholdernya. Hal ini dikarenakan menurut stakeholder adalah salah satu penyedia sumber daya untuk perusahaan dapat beraktivitas.

Resource Based Theory menyatakan bahwa sumber daya yang dimiliki perusahaan menjadi salah satu faktor agar perusahaan menjadi unggul dalam persaingan dan mencapai performance jangka panjang yang baik. Resource yang langka juga mempunyai pengaruh agar suatu perusahaan dapat bertahan lama, tidak mudah untuk ditiru, dikirim, atau digantikan

\footnotetext{
1 Fitri Nurlatifah and Sepky Mardian, 'Kinerja Keuangan Perusahaan Asuransi Syariah Di Indonesia: Surplus on Contribution', Akuntabilitas, 9.1 (2016), 73-96 <https://doi.org/10.15408/akt.v9i1.3590>.

2 Daniel Mehari and Tilahun Aemiro, 'Firm Specific Factors That Determine Insurance Companies' Performance in Ethiopia', European Scientific Journal, 9.10 (2013), 1857-7881.

3 Teklit Atsbeha Berhe and Prof. Jasmindeep Kaur, 'Determinants of Insurance Companies' Profitability Analysis of Insurance Sector in Ethiopia', 7.4 (2017), 124-37.
} 
oleh perusahaan lain Keputusan pendanaan perusahaan diurutkan dengan teori pecking order. Pendanaan internal yang berasal dari laba ditahan (hasil operasi perusahaan) lebih diutamakan penggunaannya dari pada dana yang berasal dari luar perusahaan seperti hutang.

Peneliti mengukur size (ukuran perusahaan) dengan total aset perusahaan, karena total aset perusahaan dapat dijadikan ukuran dalam mencerminkan besar kecilnya ukuran dari suatu perusahaan. Perusahaan yang mempunyai ukuran besar dapat digambarkan perusahaan tersebut mempunyai kemampuan lebih untuk mendapatkan profit dan relatif lebih stabil dalam menjalankan usaha dari pada perusahaan yang berukuran kecil sehingga menyebabkan kinerja keuangan meningkat. Selain itu, dengan besarnya sumber daya bisa menjadi pendorong suatu perusahaan untuk melaksanakan kegiatan investasi, dimana investasi tersebut bisa berupa bentuk aset lancar ataupun aset tetap. Berdasarkan stakeholder theory, stakeholder memiliki kemampuan untuk menyediakan sumber daya, sumber daya tersebut sangat berguna untuk menjalankan aktivitas perusahaan. Selain itu, dalam dalam resource-based theory dijelaskan bahwa untuk menciptakan keunggulan dalam bersaing, resource yang berharga dan langka sangat dibutuhkan, sehingga dapat menjadikan lebih tingginya kinerja keuangan. Hasil penelitian Nurlatifah dan Mardian, ${ }^{4}$ jugan Putri dan Lestari, ${ }^{5}$ menunjukan bahwa ukuran perusahaan berpengaruh dengan arah positif pada financial performance.

H1: Size (ukuran perusahaan) mempunyai pengaruh positif dan signifikan terhadap financial performance.

Besarnya aset dengan dibiayai hutang atau biaya dari pihak luar dapat diukur dengan rasio hutang atau leverage. Apabila perusahaan mempunyai leverage (rasio hutang) yang tinggi, beban yang ditanggung perusahaan juga akan menjadi semakin tinggi sehingga kinerja keuangan akan menurun. Selain itu, apabila leverage (rasio hutang) perusahaan tinggi, maka risiko hutangnya semakin tinggi dan berakibat pada kondisi kebangkrutan. Dalam pecking order theory penggunaan dana intern perusahaan yang bersumber dari retained earning (hasil operasi perusahaan) lebih banyak digunakan dari pada penggunaan dana ekstern perusahaan seperti hutang. Hasil penelitian Ludijanto, ${ }^{6}$ Nurlatifah dan Mardian; ${ }^{7}$ dan Kurniawan, ${ }^{8}$ menunjukan bahwa leverage (rasio hutang) berpengaruh dengan arah negatif pada financial performance perusahaan.

H2: Leverage (rasio hutang) mempunyai pengaruh negatif dan signifikan terhadap financial performance.

Satoto, ${ }^{9}$ mengukur variabel age (umur perusahaan) dari lamanya perusahaan tercatat secara resmi (dalam satuan tahun) hingga tahun penelitian sehingga dapat menghasilkan bahwa kinerja keuangan perusahaan dapat terpengaruh oleh seberapa lama perusahan

\footnotetext{
${ }^{4}$ Nurlatifah and Mardian, 'Kinerja Keuangan Perusahaan Asuransi Syariah Di Indonesia: Surplus on Contribution'.

${ }^{5}$ Ajeng Permata Putri and Henny Setyo Lestari, 'Faktor Spesifik Yang Menentukan Kinerja Perusahaan Asuransi Yang Terdaftar Di Bursa Efek Indonesia', E-Journal Manajemen Fakultas Ekonomi, 1.2 (2014), 1-20.

6 Shella Ekawati Ludijanto, Siti Ragil Handayani, and Raden Rustam Hidayat, 'Pengaruh Analisis Leverage Terhadap Kinerja Keuangan Perusahaan ( Studi Pada Perusahaan Property Dan Real Estate Yang Listing Di BEI Tahun 2010-2012 )', Jurnal Administrasi Bisnis, 8.1 (2014), 1-8.

7 Nurlatifah and Mardian, 'Kinerja Keuangan Perusahaan Asuransi Syariah Di Indonesia: Surplus on Contribution'.

8 Ivan Deas Kurniawan, 'Pengaruh Leverage, Aktivitas, Dan Arus Kas Perusahaan Terhadap Kinerja Keuangan Perusahaan (Studi Empiris Pada Perusahaan Manufaktur Yang Terdaftar Di BEI)’ (Universitas Negeri Padang, 2014).

9 Shinta Heru Satoto, 'Strategi Diversifikasi Terhadap Kinerja Perusahaan', Jurnal Keuangan Dan Perbankan, 13.2 (2009), 280-87.
} 
melakukan operasi. Apabila umur perusahaan semakin bertambah, maka akan semakin banyak pengalaman perusahaan dalam menjalankan bisnis. Selain itu, perusahaan yang umurnya lebih lama cenderung mempunyai reputasi yang tinggi di masyarakat sehingga perusahaan dapat memanfaatkan reputasi tersebut dalam menarik stakeholder. Peluang bisnis juga dapat dimanfaatkan dengan baik oleh perusahaan dan dapat bertahan dalam menghadapi pesaing sehingga mengakibatkan kinerja keuangan meningkat. Selain Perusahaan dapat memanfaatkan peluang bisnis untuk perekonomian, suatu perusahaan juga harus dapat bertahan dengan persaingan agar kinerja keuangannya akan terus meningkat. Berdasarkan teori stakeholder suatu operasi dalam perusahaan tidak hanya untuk kepentingan pemilik perusahaan, akan tetapi harus bermanfaat terhadap stakeholdernya untuk membantu dalam membuat keputusan yang tepat. Para investor akan memberikan investasi kepada perusahaan yang sekiranya dapat dipercaya untuk mengelola investasinya. Perusahaan yang lebih lama umurnya menunjukan bahwa perusahaan tersebut mempunyai kemungkinan lebih dapat dipercaya oleh para investor. Hasil penelitian Manik, ${ }^{10}$ menunjukan bahwa age (umur perusahaan) mempunyai pengaruh dengan arah positif pada financial performance.

H3: Age (umur perusahaan) mempunyai pengaruh positif dan signifikan terhadap financial performance.

Pertumbuhan volume of capital dapat dikalkulasi dengan rumus yaitu nilai buku ekuitas pada tahun penelitian dikurangi nilai buku ekuitas tahun sebelumnya dan dibagi dengan nilai buku ekuitas tahun sebelumnya. Volume of capital merupakan bentuk dari pendanaan internal perusahaan. Semakin tinggi pertumbuhan pendanaan dari internal perusahaan maka perusahaan akan menjalankan aktivitas operasional dengan lancar karena modal perusahaan tercukupi sehingga akan meningkatkan kinerja keuangan perusahaan. Berdasarkan teori pecking order dijelaskan mengenai perusahaan dengan sumber dana internalnya yang terhitung lebih besar dari pada dana eksternalnya, maka perusahaan tersebut menggunakan dana yang bersumber dari intern terlebih dahulu dalam menjalankan operasional perusahaan. Variabel pertumbuhan volume of capital merupakan kebaruan dari penelitian ini. Malik ${ }^{11}$ dan Ulum, ${ }^{12}$ dalam penelitiannya mencerminkan bahwasanya volume of capital berpengaruh dengan arah positif pada financial performance.

H4: Pertumbuhan volume of capital mempunyai pengaruh positif dan signifikan terhadap financial performance.

Dana tabarru' adalah dana digunakan untuk antar nasabah dapat saling tolong menolong, dan dana tersebut tidak boleh dijadikan dana perusahaan oleh perusahaan asuransi syariah. Apabila dana tabarru' meningkat, maka bagi hasil investasi serta pendapatan ujrah yang berasal dari dana tabarru' yang akan diterima perusahaan meningkat sehingga kinerja keuangan perusahaan juga meningkat. Dalam resourches based theory, resources (sumber daya) yang bersifat langka dan unik dapat menjadikan perusahaan lebih unggul dalam persaingan dengan perusahaan lain, sehingga resource yang dimiliki tidak mudah ditiru, ditransfer, atau digantikan oleh perusahaan lain. Dana tabarru' merupakan

10 Tumpal Manik, 'Analisis Pengaruh Kepemilikan Manajemen, Komisaris Independen, Komite Audit, Umur Perusahaan Terhadap Kinerja Keuangan (Studi Empiris Perusahaan Property \&Real Estate Di BEI)', Jurnal Akuntansi Dan Keuangan, 2.2 (2011), 25-36.

11 Hifza Malik, 'Determinants of Insurance Comapnies Profitability: An Analysis of Insurance Sector of Pakisan', Academic Research Journal, 1.3 (2011), 315-22.

12 Ihyaul Ulum, 'Pengaruh Intellectual Capital Terhadap Kinerja Keuangan Perbankan Syari'ah Di Indonesia', EKUITAS (Jurnal Ekonomi Dan Keuangan) (Universitas Diponegoro, 2007). 
salah satu sumber daya yang langka dan unik yang hanya ada ada pada asuransi syariah. Adanya dana tabarru' ini menjadi ciri khas dari asuransi syariah yang tidak ada dalam asuransi konvensional. Hasil penelitian Novi, ${ }^{13}$ menunjukan bahwa antara dana tabarru' dengan financial performance perusahaan terdapat hubungan dengan arah positif.

H5: Dana Tabarru' mempunyai pengaruh positif dan signifikan terhadap financial performance.

Komisaris independen merupakan salah satu anggota dari dewan komisaris yang tidak mempunyai keterikatan dengan pihak manajemen, shareholder perusahaan, serta anggota dewan komisaris yang lain. Selain itu, komisaris independen mempunyai sifat yang bebas dan tidak pula berhubungan dengan bisnis sehingga tidak ada pengaruh dengan komisaris independen untuk bertindak secara independen dan adil dan melakukan tugas hanya untuk kepentingan perusahaan. Rasio komisaris independen dapat dikalkulasikan dengan rumus yaitu pembagian antara jumlah komisaris independen dengan jumlah seluruh anggota dari dewan komisaris. Fungsi dari dewan komisaris independen adalah untuk mengawasi manajer sehingga dapat meminimalisir kesalahan dalam menyajikan laporan keuangan dan menyebabkan kinerja keuangan akan menjadi lebih baik. Berdasarkan stakeholder theory perusahaan mempunyai tanggungjawab kepada seluruh stakeholder perusahaan. Komisaris independen merupakan salah satu stakeholder perusahaan. penelitian Widyati, ${ }^{14}$ menunjukan bahwa antara komisaris independent terhadap kinerja keuangan terdapat pengaruh positif.

H6: Rasio Komisaris Independen mempunyai pengaruh positif dan signifikan terhadap financial performance.

Pertumbuhan investasi adalah perubahan volume investasi dari tahun ke tahun sehingga dapat diketahui berapa jumlah peningkatan investasi perusahaan asuransi syariah. Apabila investasi perusahaan meningkat dan semakin menunjukkan pertumbuhan maka hasil investasi perusahaan akan menunjukkan peningkatan yang nantinya dapat meningkatkan pendapatan perusahaan sehingga akan meningkat pula kinerja keuangan perusahaan. Dalam resource-based theory, resources yang mempunyai sifat unik dan langka dapat menjadikan perusahaan lebih unggul dalam persaingan dengan perusahaan lain. Salah satu keunggulan sumber daya yang ada diperusahaan adalah dengan berinvestasi. Variabel pertumbuhan investasi juga meruapakan kebaruan dari penelitian ini. Penelitian Hanifaturrosida, ${ }^{15}$ Mubarok, ${ }^{16}$ dan Sari, ${ }^{17}$ menunjukan bahwa antara investasi dengan financial performance terdapat pengaruh dengan arah positif.

H7: Pertumbuhan investasi mempunyai pengaruh positif dan signifikan terhadap financial performance.

\footnotetext{
13 Puspitasari Novi, 'Determinan Proporsi Dana Tabarru' Pada Lembaga Keuangan Asuransi Umum Syariah', Jurnal Akuntansi Dan Keuangan Indonesia, 13.2 (2016), 160-73.

14 Maria Fransisca Widyati, 'Pengaruh Dewan Direksi, Komisaris Independen, Komite Audit, Kepemilikan Manajerial Dan Kepemilikan Institusional Terhadap Kinerja Keuangan', Jurnal Ilmu Manajemen, 1.1 (2013), 23449.

15 Hanifaturrosida and Julia Noermawati, 'Profitabilitas Pada Perusahaan Asuransi Jiwa Syariah Di Indonesia Periode 2014-2016 the Effects of Premium Income, Claims Expense, Investment and Underwriting on Profitability', 2016.

16 Salman Zakki Syahriel Mubarok, 'Pengaruh Pendapatan Premi, Klaim Dan Hasil Investasi Terhadap Surplus Underwriting Dana Tabarru’ Pada Perusahaan Asuransi Umum Syariah Di Indonesia' (UMS, 2018).

17 Laras Mutiara Sari, 'Pengaruh Pendapatan Premi, Klaim, Dan Hasil Invetasi Terhadap Hasil Underwriting Dan Laba Pada Persahaan Asuransi Jiwa Syariah Di Indonesia Periode 2013-2018' (UIN Syarif Hidayatullah, 2018).
} 


\section{METODE PENELITIAN}

Studi yang dilakukan oleh peneliti berjenis penelitian kuantitatif yang dilakukan di perusahaan asuransi umum syariah dan asuransi umum unit syariah di Indonesia periode tahun 2015-2017. Data dalam studi ini merupakan data sekunder yang berupa laporan keuangan tahunan perusahaan yang dipublikasikan oleh OJK (Otoritas Jasa Keuangan) serta website perusahaan masing-masing. Jumlah populasi sebanyak 30 perusahaan. Sampel dipilih secara purposive sampling sehingga terdapat 21 perusahaan yang terpilih menjadi sampel. Variabel independen yang digunakan dalam studi ini berupa financial performance yang diukur dengan ROA (Return on Asset) dan variabel independennya berupa size (ukuran perusahaan), leverage (rasio hutang), age (umur perusahaan), pertumbuhan volume of capital, dana tabarru', rasio komisaris independen dan pertumbuhan investasi.

Data pengukuran variabel penelitian disajikan pada tabel berikut ini:

Tabel 1

Variabel Penelitian

\begin{tabular}{|c|c|c|}
\hline Variabel & Definisi & Indikator \\
\hline $\begin{array}{l}\text { Return on Asset } \\
(R O A)\end{array}$ & $\begin{array}{l}\text { Return on Asset (ROA) } \\
\text { merupakan rasio yang } \\
\text { diukur dari jumlah } \\
\text { keuntungan yang akan } \\
\text { didapatkan atas setiap } \\
\text { rupiah aktiva yang } \\
\text { dipunyai } \\
\text { perusahaan. }\end{array}$ & $\begin{array}{l}R O A=\frac{\text { Net Income atau Earving AfterTax }}{\text { Tntal Asspt. }} \\
\text { Tertius\&Christiawan } 18\end{array}$ \\
\hline $\begin{array}{l}\text { Size (Ukuran } \\
\text { Perusahaan) }\end{array}$ & $\begin{array}{lr}\text { Size } & \text { (ukuran } \\
\text { perusahaan) adalah } \\
\text { suatu ukuran yang } \\
\text { dapat dinilai untuk } \\
\text { mengukur kecil atau } \\
\text { besarnya } & \text { suatu } \\
\text { perusahaan. } & \end{array}$ & SIZE $=$ Ln Total Asset \\
\hline $\begin{array}{l}\text { Leverage } \\
\text { (Rasio Hutang) }\end{array}$ & $\begin{array}{l}\text { Leverage (rasio hutang) } \\
\text { adalah ukuran rasio } \\
\text { yang mencerminkan } \\
\text { berapa besar atau } \\
\text { berapa kecil suatu } \\
\text { perusahaan dibiayai } \\
\text { oleh utang }\end{array}$ & $\begin{array}{l}\text { DAR }=\frac{\text { Total Utang }}{\text { Total Asset }} \\
\text { Mehari\&Aemiro } 20\end{array}$ \\
\hline
\end{tabular}

18 Melia Aguntina Tertius and Yulius Jogi Christiawan, 'Pengaruh Good Corporate Governance Terhadap Kinerja Perusahaan', Business Accounting Review, 3.1 (2015), 223-32 <https://doi.org/10.17509/jaset.v1i1.8907>.

${ }^{19}$ Mehari and Aemiro.

20 Mehari and Aemiro. 
Determinan yang Mempengaruhi Financial Performance pada Perusahaan Asuransi Umum Syariah di Indonesia

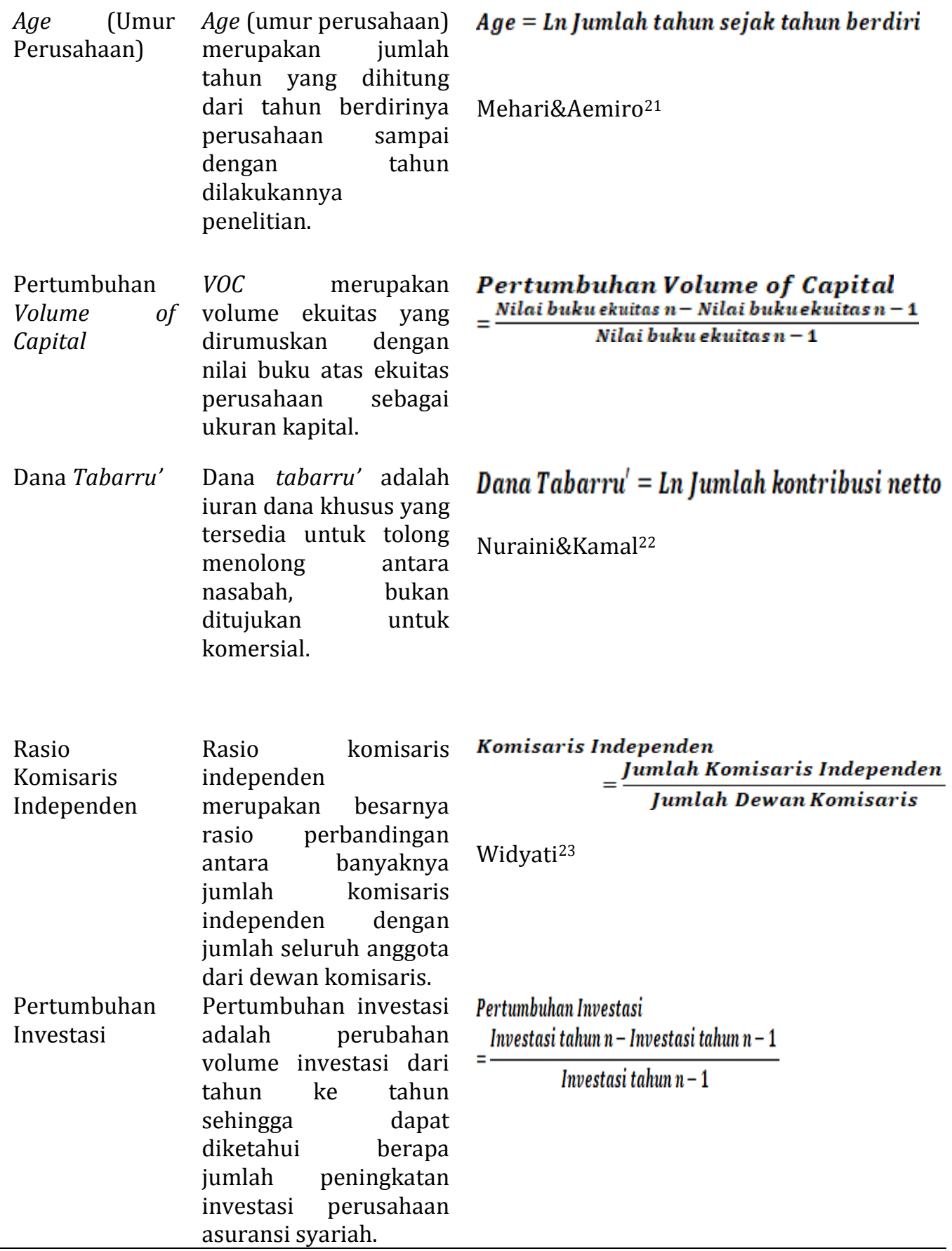

Sumber: Data Sekunder yang diolah,2019

Teknik pengambilan data menggunakan teknik dokumenter berupa data dari laporan tahunan pada tahun 2015-2017. Teknik analisis data menggunakan model panel data regression. Analisis data panel dilakukan melalui beberapa tahap diantaranya estimasi model

21 Mehari and Aemiro.

22 Nuraini and Mustafa Kamal, 'Analisis Determinan Tingkat Proporsi Dana Tabarru ' Pada Asuransi Jiwa Syariah', Jurnal Akuntansi Dan Keuangan Islam, 6.2 (2018), 143-66.

23 Widyati. 
panel data, memilih model panel data regression, pengujian asumsi klasik dan uji signifikansi. Metode estimasi model panel data regression terdiri dari Common Effect Model (CEM), Fixed Effect Model (FEM), dan Random Effect Model (REM). Pemilihan model panel data regression terdiri dari Chow Test atau Redundant Fixed Effect, Uji Hausman dan Uji Lagrange Multiplier (LM Test). Untuk memilih model mana yang lebih baik antara CEM dan FEM yaitu menggunakan Chow Test. Penggunaan Uji Hausman adalah memilih antara kedua model mana yang lebih baik antara FEM dan REM. Sementara itu, untuk menguji yang terbaik antara CEM dan REM yaitu digunakan Uji Lagrange Multiplier. Pengujian asumsi klasik dalam E views 9 terbagi menjadi dua pengujian yaitu uji multikolinearitas dan uji heteroskedastisitas. Tahap terakhir yaitu pengujian signifikansi untuk melihat koefisien determinasi (R2), Uji $F$ statistik, dan Uji t statistik.

\section{HASIL DAN PEMBAHASAN}

Hasil estimasi model panel data menggunakan CEM, FEM, dan REM. Ketiga hasil ini kemudian dipilih untuk ditentukan model panel data manakah yang terbaik. Hasil Uji Chow menunjukan nilai p-value Cross-section F yaitu sebesar 0.0737. Nilai signifikansi yang sudah ditetapkan yaitu $\alpha=0.05$ lebih kecil dari $p$ value. Maka dari itu, H1 ditolak dan H0 diterima. Ini berarti model yang terpilih antara CEM dan FEM adalah CEM.

Berdasarkan hasil Chows Test model regresi data panel yang terpilih adalah CEM. Oleh karena itulah, harus dilakukan pengujian selanjutnya yaitu dengan LM Test. Untuk menentukan model mana terbaik antara CEM dan REM yaitu menggunakan LM Tets. Berdasarkan hasil LM Test nilai $p$-value Breusch Pagan untuk both menunjukan angka 0.5131 $>\alpha=5 \%$, maka model yang terpilih adalah CEM. Dengan demikian, hasil panel data regression yang bermodel CEM digunakan sebagai landasan analisis uji hipotesis dalam studi ini.

Pengujian asumsi klasik multikolinearitas digunakan dengan nilai korelasi bivariat. Berdasarkan hasil pengujian, tidak mempunyai masalah multikolinearitas dalam studi ini dikarenakan nilai korelasi antara variabel independen nilainya kuarang dari 0.8. Uji glejser digunakan untuk melaksanakan pengujian asumsi klasik yaitu heteroskedastisitas. Dalam hasil uji glejser menunjukan tidak adanya permasalahan mengenai heteroskedastisitas dalam penelitian ini karenakan nilai p-value seluruh variabel independen diatas 0.05 . Nilai adjusted R2 sebesar 0,5670 mencerminkan variabel independen mampu menjelaskan luas pengungkapan ISR sebesar 56,70\%. Sementara itu, sisanya 43,30\% ditunjukan variabel yang lain selain model dalam studi ini. Uji F Statistik menunjukan F-hitung sebanyak 11.7643 > Ftabel sebanyak 1.6720, artinya variabel independen mempengaruhi financial performance secara bersama-sama. Berikut ini disajikan data hasil penelitian dalam pengujian hipotesis:

Tabel 2.

Hasil Pengujian Hipotesis

\begin{tabular}{|c|c|c|c|c|}
\hline \multicolumn{2}{|c|}{ Pengaruh parsial } & Koefisien & Sig. & Keputusan \\
\hline 1 & $\begin{array}{l}\text { Size (ukuran perusahaan) } \\
\text { mempunyai pengaruh positif dan } \\
\text { signifikan terhadap financial } \\
\text { performance }(\mathrm{H} 1)\end{array}$ & 0.1681 & 0.0010 & Diterima \\
\hline 2 & $\begin{array}{l}\text { Leverage (Rasio utang) tidak } \\
\text { mempunyai pengaruh yang } \\
\text { signifikan terhadap financial } \\
\text { performance }(\mathrm{H} 2)\end{array}$ & -0.1258 & 0.1032 & Ditolak \\
\hline 3 & $\begin{array}{l}\text { Age (umur perusahaan) } \\
\text { mempunyai pengaruh positif dan } \\
\text { signifikan terhadap financial }\end{array}$ & 0.0756 & 0.0040 & Diterima \\
\hline
\end{tabular}


performance (H3)

$4 \quad$ Pertumbuhan volume of capital mempunyai pengaruh positif dan signifikan terhadap financial performance $(\mathrm{H} 4)$

5 Dana tabarru' tidak mempunyai pengaruh yang signifikan terhadap financial performance (H5) Rasio komisaris independen tidak mempunyai pengaruh yang signifikan terhadap financial performance (H6)
0.2005

0.0008

Diterima

$\begin{array}{lll}-0.0059 & 0.5167 \quad \text { Ditolak }\end{array}$

0.0199

0.7198

Ditolak

$-0.0825$

0.0116

Ditolak mempunyai pengaruh negatif dan signifikan terhadap financial performance (H7)

Sumber: Data yang diolah, 2019

\section{Pengaruh Size (Ukuran Perusahaan) terhadap Financial Performance}

Hasil uji hipotesis menunjukan antara size (ukuran perusahaan) terhadap kinerja keuangan mempunyai pengaruh dengan arah yang positif dan signifikan (H1 diterima). Hasil studi ini mendukung konsep teori stakeholder. Apabila ukuran perusahaan semakin besar, maka pengelolaan dan penggunaan sumber daya oleh perusahaan akan semakin besar Artinya, stakeholder yang dimiliki juga semakin besar. Hal tersebut disebabkan karena stakeholder mempunyai kemampuan untuk menyediakan resourches yang bermanfaat untuk melakukan kegiatan operasional perusahaan. Ketersediaan resourches yang memadai mendorong manajemen untuk menjalankan usaha dengan efisien dan efektif sehingga financial performance perusahaan asuransi syariah menjadi semakin meningkat. Selain itu, hasil studi ini juga sejalan dengan resource-based theory yang menyatakan mengenai banyaknya resourches yang dimiliki perusahaan dapat membuat perusahaan menjadi lebih unggul dalam hal persaingan antar perusahaan sehingga kinerja keuangan perusahaan asuransi syariah menjadi semakin meningkat.

\section{Pengaruh Leverage (Rasio Hutang) terhadap Financial Performance}

Uji hipotesis menghasilkan antara leverage (rasio utang) dengan financial performance tidak mempunyai pengaruh yang signifikan (H2 ditolak). Hasil ini tidak mendukung teori pecking order, yaitu perusahaan asuransi lebih menggunakan dana yang diperoleh dari intern perusahaan dari pada penggunaan dana dari eksternal perusahaan seperti hutang. Peneliti berasumsi bahwa pola leverage perusahaan asuransi masih bersifat fluktuatif sehingga tidak mempengaruhi kinerja keuangan. Selain itu, perusahaan asuransi syariah lebih banyak menggunakan pendanaan dari intern dibanding menggunakan dana ekstern yang ada pada asuransi syariah dalam mendanai aktivanya. Penggunaan dana eksternal pada asuransi syariah berupa akad mudharabah, wakalah bil ujrah, dan akad mudharabah mustarakah. Pada wakalah bil ujrah, perusahaan mempunyai biaya yaitu biaya ujrah, sedangkan pada akad mudharabah mustarakah perusahaan mempunyai biaya yaitu biaya bagi hasil. Kecukupan dana yang diperoleh dari dana internal membuat perusahaan tidak terlalu mengandalkan hutangnya. Oleh sebab itu, penggunaan dana internal pada asuransi syariah lebih didahulukan dari pada penggunaan dana eksternal sehinga leverage perusahaan tidak berpengaruh secara signifikan pada financial performance perusahaan. 


\section{Pengaruh Age (Umur Perusahaan) terhadap Financial Performance}

Uji hipotesis menghasilkan antara age dengan financial performance terdapat hubungan dengan arah yang positif serta signifikan (H3 diterima). Hasil studi ini sesuai dengan stakeholder theory. Teori stakeholder didasarkan pada hubungan yang dimiliki antara stakeholder dengan perusahaan. Perusahaan mempunyai tannggung jawab kepada seluruh pemangku kepentingan, tidak hanya bertanggungjawab kepada pemegang dan pemilik saham saja untuk membantu dalam membuat keputusan yang tepat. Para investor akan memberikan investasi kepada perusahaan yang sekiranya dapat dipercaya untuk mengelola investasinya. Perusahaan yang lebih lama umurnya menunjukan bahwa perusahaan tersebut mempunyai kemungkinan lebih dapat dipercaya oleh para investor. Selain itu, perusahaan yang umurnya lebih lama mempunyai pengalaman usaha dan manajemen yang lebih matang sehingga dapat menjalankan kegiatan operasional perusahaan dengan efisien dan efektif yang menyebabkan financial performance menjadi meningkat.

\section{Pengaruh Pertumbuhan Volume of Capital terhadap Financial Performance}

Hasil uji menghasilkan antara pertumbuhan volume of capital terhadap kinerja keuangan terdapat pengaruh dengan arah yang positif serta signifikan (H4 diterima). Semakin tinggi pertumbuhan volume of capital atau laba ditahan dalam perusahaan, maka juga akan berpengaruh terhadap kinerja keuangannya yaitu akan semakin meningkat. Berdasarkan hasil penelitian yang dilakukan peneliti, hasilnya sejalan dengan dengan teori pecking order, yaitu perusahaan lebih menggunakan pendanaan dari intern atau berasal dari operasi perusahaan (laba ditahan) terlebih dahulu dibanding menggunakan pendanaan dari ekstern perusahaan. Selain itu, pendanaan dari intern usaha merupakan dana yang paling aman dan tidak mempunyai biaya seperti hutang. Apabila dana internal digunakan oleh perusahaan, maka tidak ada biaya yang dapat mengurangi laba perusahaan sehingga dapat menaikkan financial performance.

\section{Pengaruh Dana Tabarru' terhadap Financial Performace}

Uji hipotesis menghasilkan antara dana tabarru' terhadap financial performance tidak berpengaruh secara signifikan (H5 ditolak). Hasil studi tidak sesuai dengan resourches based theory, resources yang langka dan unik dapat menjadikan perusahaan asuransi syariah menjadi lebih unggul dalam persaingan dengan asuransi konvensional. Dana tabarru' merupakan salah satu sumber daya yang langka dan unik yang hanya ada pada asuransi syariah saja dan tidak terdapat dalam asuransi konvensional. Akan tetapi, di sisi lain dana tabarru' bukan merupakan hak milik perusahaan dan pencatatan dana tabarru' dibedakan secara terpisah dengan dana perusahaan sehingga dana tabarru' tidak berpengaruh secara signifikan pada financial performance.

\section{Pengaruh Rasio Komisaris Independen terhadap Financial Performance}

Uji hipotesis menghasilkan antara rasio komisaris independen terhadap financial performance tidak berpengaruh secara signifikan (H6 ditolak). Studi ini tidak sejalan dengan teori stakeholder yang menyatakan bahwa perusahaan mempunyai tanggungjawab kepada seluruh stakeholder perusahaan. Peneliti berasumsi bahwa besarnya rasio komisaris independen pada asuransi syariah tidak menunjukan efektivitas kinerja dari dewan komisaris independen tersebut. POJK 33/POJK04/2014 dalam Pasal 20 (3) mewajibkan minimal 30\% dari semua anggota dewan komisaris adalah komisaris independen. Besarnya rasio komisaris independen tidak menunjukan keefektifan dan keefisienan dalam melaksanakan fungsinya. Sementara itu, banyaknya jumlah komisaris independen hanya 
menunjukan bentuk kepatuhan peraturan saja sehingga tidak mempunyai pengaruh yang signifikan pada financial performance perusahaan asuransi syariah.

\section{Pengaruh Pertumbuhan Investasi terhadap Financial Performance}

Uji hipotesis menghasilkan antara pertumbuhan investasi terhadap financial performance mempunyai pengaruh negatif serta signifikan (H7 ditolak). Studi ini bertentangan dengan Resource Based Theory yang menjyatakan bahwa perusahaan yang memiliki resources tinggi akan membuat perusahaan menjadi lebih unggul dibanding perusahaan lain sehingga mencapai kinerja yang baik. Keunggulan sumber daya pada perusahaan adalah dengan berinvestasi. Peneliti berasumsi bahwa keuntungan yang didapatkan dari hasil investasi pada asuransi syariah cenderung rendah serta besarnya risiko kerugian yang cukup tinggi atas investasi tersebut sehingga pertumbuhan investasi berpengaruh dengan arah yang negatif serta signifikan pada financial performance. Maka dari itu, apabila pertumbuhan investasi semakin tiggi, maka akan menurunkan kinerka keuangan perusahaan.

\section{PENUTUP}

Simpulan dari studi ini yaitu size (ukuran perusahaan), age (umur perusahaan), dan pertumbuhan volume of capital terhadap financial performance mempunyai pengaruh dengan arah yang positif dan signifikan. Pertumbuhan investasi pada financial performance mempunyai pengaruh negatif serta signifikan. Sementara itu, leverage (rasio hutang), dana tabarru' dan rasio komisaris independen pada financial performance asuransi syariah tidak ada pengaruh yang signifikan.

\section{DAFTAR PUSTAKA}

Berhe, T. A., \& Kaur, P. J. (2017). Determinants of insurance companies' profitability Analysis of insurance sector in Ethiopia, 7(4), 124-137.

Cahyadi, I. J. (2017). Pengaruh Karakteristik Perusahaan Terhadap Struktur Modal Perusahaan, 19(2).

Ghozali, I., \& Chariri, A. (2014). Teori Akuntansi International Financial Reports (IFRS) Edisi 4. Semarang: Badan Penerbit Universitas Diponegoro.

Hanifaturrosida, \& Noermawati, J. (2016). Profitabilitas Pada Perusahaan Asuransi Jiwa Syariah Di Indonesia Periode 2014-2016 the Effects of Premium Income , Claims Expense, Investment and Underwriting on Profitability.

Harisnawati, R., Ulum, I., \& Syam, D. (2017). Pengaruh Intellectual Capital Performance Terhadap Intensitas Pelaporan Modal Intelektual. Jurnal Reviu Akuntansi Dan Keuangan, 7(1), 941-949. https://doi.org/10.22219/jrak.v7i1.08

Isbandah, Y. (2015). Pengaruh ESOP, Leverage, dan Ukuran perusahaan terhadap Kinerja Keuangan di Bursa Efek Indonesia. Jurnal Riset Ekonomi Dan Manajemen, 15(1), 2841.

Kurniawan, I. D. (2014). Pengaruh Leverage, Aktivitas, dan Arus Kas Perusahaan Terhadap Kinerja Keuangan Perusahaan (Studi Empiris Pada Perusahaan Manufaktur yang Terdaftar di BEI). Universitas Negeri Padang.

Ludijanto, S. E., Handayani, S. R., \& Hidayat, R. R. (2014). Pengaruh Analisis Leverage terhadap Kinerja Keuangan Perusahaan ( Studi pada Perusahaan Property dan Real Estate yang Listing di BEI Tahun 2010-2012 ). Jurnal Administrasi Bisnis, 8(1), 1-8.

Malik, H., \& Fitri, anisa nur. (2011). Determinants of Insurance Comapnies Profitability: An Analysis of Insurance Sector of Pakisan. Academic Research Journal, 1(3), 315-322. 
Manik, T. (2011). Analisis Pengaruh Kepemilikan Manajemen, Komisaris Independen, Komite Audit, Umur Perusahaan terhadap Kinerja Keuangan (Studi Empiris Perusahaan Property \&Real Estate di BEI). Jurnal Akuntansi Dan Keuangan, 2(2), 25-36.

Mehari, D., \& Aemiro, T. (2013). Firm Specific Factors That Determine Insurance Companies' Performance in Ethiopia. European Scientific Journal, 9(10), 1857-7881.

Mubarok, S. Z. S. (2018). Pengaruh Pendapatan Premi, Klaim dan Hasil Investasi terhadap Surplus Underwriting Dana Tabarru' pada Perusahaan Asuransi Umum Syariah di Indonesia. UMS.

Munsaidah, S., Andini, R., \& Supriyanto, A. (2016). Analisis Pengaruh Firm Size, Age, Profitabilitas, Leverage, dan Growth Perusahaan terhadap Corporate Social Rerponsibility (CSR) pada Perusahaan Property dan Real Estate yang Terdaftar di Bursa Efek Indonesia Pada Tahun 2010-2014. Journal of Accounting, 2(2), 1-11.

Novi, P. (2016). Determinan Proporsi Dana Tabarru' pada Lembaga Keuangan Asuransi Umum Syariah. Jurnal Akuntansi Dan Keuangan Indonesia, 13(2), 160-173.

Nuraini, \& Kamal, M. (2018). Analisis Determinan Tingkat Proporsi Dana Tabarru ' Pada Asuransi Jiwa Syariah. Jurnal Akuntansi Dan Keuangan Islam, 6(2), 143-166.

Nurlatifah, A. F., \& Mardian, S. (2016). Kinerja Keuangan Perusahaan Asuransi Syariah Di Indonesia: Surplus on Contribution. Jurnal Ilmu Akuntansi, 9(1), 73-96. https://doi.org/10.15408/akt.v9i1.3590

Puspitasari, N. (2011). Sejarah Perkembangan Asuransi Islam serta Perbedaanya dengan Asuransi Konvensional. Jeam, 10(1), 35-47. https://doi.org/10.1016/j.stueduc.2018.05.006

Putri, A. P., \& Lestari, H. S. (2014). Faktor Spesifik yang Menentukan Kinerja Perusahaan Asuransi yang Terdaftar di Bursa efek Indonesia. E-Journal Manajemen Fakultas Ekonomi, 1(2), 1-20.

Rahmawati, T. (2017). Analisis Penngaruh Premi, Dana Tabarru', Klaim dan Likuiditas terhadap Solvabilitas Dana Perusahaan Asuransi Jiwa Syariah di Indonesia (periode 2014-2016).

Saniatusilma, H., \& Suprayogi, N. (2015). Manajemen risiko Dana Tabarru' PT Asuransi Jiwa Syariah Al Amin. Jesit, 49(23-6), 22-23.

Sari, L. M. (2018). Pengaruh Pendapatan Premi, Klaim, dan Hasil Invetasi Terhadap Hasil Underwriting dan Laba Pada Persahaan ASuransi Jiwa Syariah di Indonesia Periode 2013-2018. UIN Syarif Hidayatullah.

Satoto, S. H. (2009). Strategi Diversifikasi Terhadap Kinerja Perusahaan. Jurnal Keuangan Dan Perbankan, 13(2), 280-287.

Sektor, A., Dari, A., \& Malik, H. (2011). FAKTOR ASURANSI PERUSAHAAN PROFITABILITAS :, $1(3), 315-321$.

Tertius, M. A., \& Christiawan, Y. J. (2015). Pengaruh Good Corporate Governance Terhadap Kinerja Perusahaan. Business Accounting Review, 3(1), 223-232. https://doi.org/10.17509/jaset.v1i1.8907

Ulum, I. (2007). Pengaruh Intellectual Capital Terhadap Kinerja Keuangan Perbankan Syari'ah Di Indonesia. EKUITAS (Jurnal Ekonomi dan Keuangan). Universitas Diponegoro. https://doi.org/10.24034/j25485024.y2016.v20.i3.1838

Widyati, M. F. (2013). Pengaruh Dewan Direksi, Komisaris Independen, Komite Audit, Kepemilikan Manajerial dan Kepemilikan Institusional terhadap Kinerja Keuangan. Jurnal Ilmu Manajemen, 1(1), 234-249. 